\title{
PENGARUH PENERAPAN E-SPT, KESADARAN WAJIB PAJAK DAN SANKSI PERPAJAKAN TERHADAP KEPATUHAN WAJIB PAJAK DI KPP PRATAMA KARAWANG UTARA
}

\author{
Gusti Denny Alfarisi ${ }^{1}$ \\ Endang Mahpudin ${ }^{2}$ \\ Universitas Singaperbangsa Karawang, Jawa Barat, Indonesia ${ }^{1,2}$ \\ Email : 1610631030126@ @student.unsika.ac.id ${ }^{1}$ \\ endang.mahpudin@fe.unsika.ac.id ${ }^{2}$
}

\begin{abstract}
This study aims to determine the effect of E-SPT Application, Taxpayer Awareness, and Tax Sanctions on Taxpayer Compliance at KPP Pratama Karawang Utara. The sampling technique in this study was carried out using purposive sampling. The data collection method used in this study was to distribute questionnaires to individual taxpayers who were used as research samples. Testing and data analysis were tested using multiple regression analysis. The results showed that (1) The implementation of E-SPT partially has a positive and significant effect on Taxpayer Compliance, (2) Taxpayer Awareness partially has a positive and significant effect on Taxpayer Compliance, (3) Partially Tax Sanctions have a positive and significant effect. to Taxpayer Compliance. In addition, simultaneously the research results show that (4) Implementation of E-SPT, Taxpayer Awareness, and Tax Sanctions simultaneously have a positive and significant effect on Taxpayer Compliance.
\end{abstract}

Keywords : E-SPT Application; Taxpayer Awareness; Taxpayer Compliance.

\section{ABSTRAK}

Penelitian ini bertujuan untuk mengetahui Pengaruh Penerapan E-SPT, Kesadaran Wajib Pajak, dan Sanksi Perpajakan Terhadap Kepatuhan Wajib Pajak di KPP Pratama Karawang Utara.Teknik penentuan sampel dalam penelitian ini dilakukan dengan menggunakan purposive sampling. Metode pengumpulan data yang digunakan pada penelitian ini adalah dengan membagikan kuesioner kepada wajib pajak orang pribadi yang dijadikan sebagai sampel penelitian. Pengujian dan analisis data dilakukan diuji dengan menggunakan analisis regresi berganda. Hasil penelitian menunjukan bahwa (1) Penerapan E-SPT secara parsial berpengaruh positif dan signifikan terhadap Kepatuhan Wajib Pajak, (2) Kesadaran Wajib Pajak secara parsial berpengaruh positif dan signifikan terhadap Kepatuhan Wajib Pajak, (3) Sanksi Perpajakan secara parsial berpengaruh positif dan signifikan terhadap Kepatuhan Wajib Pajak. Selain itu secara simultan hasil penelitian menunjukan bahwa (4) Penerapan E-SPT, Kesadaran Wajib Pajak, dan Sanksi Perpajakan secara simultan berpengaruh positif dan signifikan terhadap Kepatuhan Wajib Pajak.

Kata kunci: Penerapan E-SPT; Kesadaran Wajib Pajak; Sanksi Perpajakan; Kepatuhan Wajib Pajak. 


\section{PENDAHULUAN}

Pajak merupakan pendapatan terbesar dalam penerimaan Negara. Dalam hal ini, pemerintah terus berupaya dengan meningkatkan potensi penerimaan pajak yang besar, oleh karena itu wajib pajak harus taat dan ikut serta membantu pemerintah dan Negara dalam usaha meningkatkan kesejahteraan rakyat Indonesia. Berdasarkan data dari Direktorat Jenderal Pajak (DJP) penerimaan pajak diharapkan dapat meningkat setiap tahunnya sebab hal ini akan sangat mempengaruhi Anggaran Penerimaan dan Belanja Negara (APBN).

Peran pajak dalam perekonomian di Indonesia terbilang sangat penting. Dalam hal ini, tentu akan mempengaruhi penerimaan negara, sebab penerimaan negara yang cukup besar salah satunya adalah dari penerimaan pajak. Agar penerimaan pajak dapat meningkat setiap tahunnya maka diperlukan adanya suatu upaya yang dilakukan oleh Direktorat Jenderal Pajak (DJP). Salah satu upaya yang dilakukan adalah dengan melakukan suatu reformasi sistem perpajakan menjadi self assessment system. Dengan menggunakan sistem ini diharapkan dapat mempermudah wajib pajak dalam melakukan kewajiban perpajakannya, sistem ini menekankan kesadaran wajib pajak dalam melaksanakan kewajiban pajak sehingga diharapkan wajib pajak dapat menyetorkan pajaknya secara tepat waktu agar penerimaan pajak negara semakin meningkat (Pajak.go.id,2020). Tetapi, dalam menjalankan self assessment ini seringkali tidak berjalan sesuai dengan yang diharapkan sehingga, hal tersebut dapat berakibat pada rendahnya tingkat kepatuhan wajib pajak. Seperti yang dapat dilihat pada tabel 1 mengenai persentase tingkat kepatuhan wajib pajak orang pribadi di KPP Pratama Karawang 
Utara dalam menyampaikan SPT tahun 2015 - 2019 berikut ini :

Tabel 1.

Presetase Tingkat Kepatuhan WP OP dalam menyampaikan SPT di KPP Pratama Karawang Utara Tahun 2015-2019

\begin{tabular}{ccccc}
\hline Tahun & WP & WP OP & WP OP Yang & \% Kepatuhan \\
& OPTerdaftar & Efektif & Menyampaikan SPT & \\
\hline 2015 & 156.941 & 99.900 & 62.616 & $62.68 \%$ \\
2016 & 173.872 & 109.482 & 58.752 & $53.66 \%$ \\
2017 & 194.290 & 86.208 & 52.489 & $60.89 \%$ \\
2018 & 212.359 & 91.224 & 52.501 & $57.55 \%$ \\
2019 & 232.525 & 83.122 & 46.622 & $56.09 \%$ \\
\hline
\end{tabular}

Sumber: KPP Pratama Karawang Utara 2020

Berdasarkan tabel tersebut menunjukan bahwa terjadinya suatu kondisi yang fluktuatif terhadap tingkat kepatuhan wajib pajak orang pribadi di KPP Pratama Karawang Utara,Pada tahun 2015-2016 jumlah tingkat kepatuhan wajib pajak orang pribadi menurun sebesar 9.02\%, lalu pada tahun 2016-2017 mengalami peningkatan terhadap tingkat kepatuhan wajib pajak orang pribadi mencapai $7.23 \%$, lalu pada tahun 2017-2018 jumlah tingkat kepatuhan wajib pajak orang pribadi menurun sebesar 3.34\%, lalu pada tahun 2018-2019 jumlah tingkat kepatuhan wajib pajak orang pribadi menurun sebesar $1.46 \%$. Berdasarkan data tersebut tentu menunjukkan bahwa masih adanya satu kondisi yang memperlihatkan masih rendahnya tingkat kepatuhan wajib pajak orang pribadi di KPP Pratama Karawang Utara.

Hal tersebut tentu dapat disebabkan oleh beberapa faktor, Rahayu (2017) mengatakan bahwa terdapat beberapa faktor yang mempengaruhi kepatuhan wajib 
pajak, tiga diantaranya ialah kondisi sistem administrasi perpajakan suatu Negara, kemauan dan kesadaran wajib pajak, serta kualitas penegakan hukum perpajakan berupa sanksi perpajakan. Dalam hal ini, perilaku kepatuhan wajib pajak dapat ditentukan oleh seberapa ketat pengawasan yang dilakukan oleh otoritas pajak. Semakin efektif dan tegas ruang lingkup pengawasan, maka dapat mengurangi kecenderungan wajib pajak yang tidak patuh dalam membayar pajak.

Pada era moderenisasi yang semakin pesat, Direktorat Jenderal Pajak (DJP) terus berinovasi dalam hal pengembangan teknologi untuk mempermudah wajib pajak dalam melakukan pekerjaan yang berhubungan dengan administrasi dan pembayaran pajak. Dengan terciptanya elektronik surat pemberitahuan tahunan (E-SPT) maka dapat diharapkan wajib pajak dapat menyampaikan SPTnya secara online tanpa harus datang ke kantor pelayanan pajak (KPP).

Selain itu, untuk memberikan kontribusi kepada negara, dalam bentuk melaporkan dan membayarkan kewajiban perpajakannya maka diperlukan adanya suatu kesadaran wajib pajak. Dalam hal ini, tentu saja Masyarakat pada umumnya dan wajib pajak khususnya harus sadar akan kewajiban dalam membayar pajak, karena semua itu sudah diatur dalam Undang-undang Dasar 1945. Kesadaran wajib pajak dalam membayar pajak merupakan perilaku wajib pajak atas dasar pengetahuan, keyakinan, dan penalaran yang telah diberikan oleh sistem tertentu atas pajak tersebut (Safri, 2013)

Ada Faktor lain yang juga mempengaruhi tingkat kepatuhan wajib pajak ialah sanksi perpajakan. Sanksi perpajakan diberikan kepada wajib pajak yang tidak memenuhi peraturan dalam Undang-undang perpajakan. Sanksi yang di 
berikan kepada wajib pajak yaitu berupa sanksi administrasi seperti denda, tarif pajak lebih tinggi, bunga dan sanksi pidana yaitu kurungan penjara.

Berdasarkan faktor-faktor yang mempengaruhi wajib pajak yang telah disampaikan bahwa dalam penerapan sistem administrasi perpajakan, kesadaran wajib pajak, dan penerapan dalam kualiatas penegakan hukum perpajakan yang berupa sanksi perpajakan tentu tidak selalu berjalan sesuai yang telah direncanakan sehingga hal tersebut dapat berakibat pada tidak terealisasinya pencapaian target penerimaan pajak yang telah disusun atau ditetapkan pemerintah. Kondisi tersebut dapat kita lihat pada tabel berikut ini :

Tabel 2.

Target dan Realisasi Penerimaan Pajak di KPP Pratama Karawang Utara Tahun 2015-2019 (dalam triliun rupiah)

\begin{tabular}{llllll}
\hline Tahun & $\mathbf{2 0 1 5}$ & $\mathbf{2 0 1 6}$ & $\mathbf{2 0 1 7}$ & $\mathbf{2 0 1 8}$ & $\mathbf{2 0 1 9}$ \\
\hline \multirow{2}{*}{ Target } & 2.459 .435$. & 2.724 .517 .0 & 2.679 .589 .2 & 3.108 .727 .68 & 3.988 .615 .10 \\
& 842.021 & 60.005 & 14.053 & 9.000 & 8.000 \\
Realisasi & 1.911 .423$. & 2.370 .947 .8 & 2.945 .830 .2 & 3.327 .942 .15 & 3.685 .166 .44 \\
& 891.078 & 61.231 & 11.988 & 9.282 & 9.375 \\
Capaian & $77,72 \%$ & $87,02 \%$ & $109,93 \%$ & $107,05 \%$ & $92,39 \%$ \\
\hline Sumber: KPP Pratama Karawang Utara, 2020 & & &
\end{tabular}

Sumber: KPP Pratama Karawang Utara, 2020

Berdasarkan data pada tabel diatas menunjukkan bahwa di KPP Pratama Karawang Utara pada tahun 2015-2019 realisasi penerimaan pajak seringkali tidak mencapai target yang telah di tetapkan. Dapat dilihat pada tahun 2015 kurangnya pencapaian penerimaan pajak sebesar 22,28\%, pada tahun 2016 kurangnya pencapaian penerimaan pajak sebesar 12,98\%, pada tahun 2017-2018 realisasi penerimaan pajak justru melebihi target yang telah ditetapkan dimana pada tahun 2017 mencapai sebesar 9,93\%, dan pada tahun 2018 mencapai sebesar 7,05\%, dan pada tahun 2019 realisasi penerimaan pajak kembali tidak mencapai yang telah 
ditetapkan dimana kurangnya pencapaian penerimaan pajak tersebut sebesar $7,61 \%$.

Penelitian yang dilakukan oleh Pebrina \& Hidayatulloh (2020) yang berjudul Pengaruh Penerapan E-SPT, Pemahaman Peraturan Peraturan Perpajakan, Sanksi Perpajakan, Dan Kualitas Pelayanan Terhadap Kepatuhan Wajib Pajak.Hasil penelitian tersebut mengatakan bahwa sanksi perpajakan berpengaruh signifikan pada kepatuhan pelaporan Wajib Orang pribadi. Halawa \& Saragih (2017) yang berjudul pengaruh Kesadaran Perpajakan, Sanksi Pajak, Sikap Fiskus Terhadap Kepatuhan Wajib Pajak Di Kpp Pratama Lubuk Pakam. Hasil penelitian tersebut mengatakan bahwa kesadaran perpajakan dan sanksi perpajakan mempunyai pengaruh positif dan signifikan terhadap variable kepatuhan wajib pajak. Berdasarkan latar belakang yang telah diuraikan, maka penulis tertarik melakukan penelitian dengan judul,"Pengaruh Penerapan E-Spt, Kesadaran Wajib Pajak, Dan Sanksi Perpajakan Terhadap Kepatuhan Wajib Pajak Di Kpp Pratama Karawang Utara”.

\section{METODE PENELITIAN}

Metode penelitian yang digunakan dalam penelitian ini metode penelitian Deskriptif dan Verifikatif dengan pendekatan kuantitatif. Metode deskriptif dilakukan untuk menganalisis satu atau lebih variabel dan tidak membuat perbandingan atau tanpa menghubungkan antara variabel satu dengan yang lain dan Metode Verifikatif bertujuan untuk mengetahui hubungan antara variabel melalui suatu pengujian hipotesis dan juga perhitungan statistik sehingga 
mendapatkan hasil pembuktian yang menunjukkan hipotesis ditolak atau diterima.

Jenis data yang digunakan dalam penelitian ini adalah data sekunder dan data primer. Data sekunder dalam penelitian ini berupa data-data yang berkenaan dengan data wajib pajak orang pribadi yang terdaftar di KPP Pratama Karawang Utara, sedangkan data primer pada penelitian ini adalah berupa hasil dari kuesioner yang telah dibagikan kepada responden yaitu wajib pajak orang pribadi yang terdaftar di KPP Pratama Karawang Utara mengenai Penerapan E-SPT, Kesadaran Wajib Pajak, Sanksi Perpajakan dan Kepatuhan Wajib Pajak yang diukur menggunakan skala likert.

Populasi yang digunakan dalam penelitian ini adalah seluruh wajib pajak orang pribadi yang terdaftar di KPP Pratama Karawang Utara, penentuan jumlah sampel dalam penelitian ini dilakukan dengan menggunakan rumus slovin dengan tingkat standar error yang di tolerir adalah 10\%, sehingga diperoleh jumlah sampel sebanyak 100 responden Wajib Pajak Orang Pribadi di KPP Pratama Karawang Utara. Pengambilan sampel dalam penelitian ini menggunakan Area Sampling. Uji Hipotesis pada penelitian ini dilakukan dengan menggunakan analisis regresi berganda. Sehingga diperoleh persamaan sebagai berikut:

$$
\mathrm{Y}=\alpha+\beta 1 . \mathrm{X} 1+\beta 2 . \mathrm{X} 2+\varepsilon
$$

Keterangan :

$Y=$ Variabel Terikat, yaitu kepatuhan wajib pajak

$\alpha=$ Konstanta

$\beta 1$ dan $\beta 2=$ Koefesien Regresi

$\mathrm{X} 1=$ Penerapan E-SPT,

$\mathrm{X} 2=$ Kesadaran Wajib Pajak

$\mathrm{X} 3=$ Sanksi Perpajakan

$\varepsilon=$ Standar Error 


\section{HASIL DAN PEMBAHASAN}

Hasil Uji Kualitas Data. Suliyanto (2018) menyatakan bahwa uji validitas ialah tingkat ketetapan dan kecermatan suatu alat ukur dalam melakukan fungsi ukurnya. Instrumen penelitian yang valid artinya instrumen tersebut mampu mengukur apa yang harus diukur dengan tepat dan cermat. Uji Validitas dalam penelitian ini ialah dengan menggunakan pendekatan person correlation, Apabila skor item memiliki korelasi signifikan positif berarti item tersebut dapat digunakan sebagai indikator untuk mengukur varibel tersebut. Kriteria pengujian uji validitas menggunakan person correlation dapat dinyatakan valid dengan kriteria sebagai berikut, dimana apabila $\mathrm{r}$ hitung > tabel, maka item-item pernyataan dinyatakan valid. Nilai $\mathrm{r}$ hitung dalam penelitian ini di peroleh dari hasil SPSS 26 sedangkan $r$ tabel pada penelitian ini adalah 0,1946. Hasil uji validitas dalam penelitian ini untuk masing-masing item pernyataan pada variabel independen dan dependen memperoleh nilai $\mathrm{r}$ hitung > dari $\mathrm{r}$ tabel sebesar 0,1946, sehingga dapat dikatakan data yang digunakan valid secara keseluruhan.

Suliyanto (2018) mengatakan bahwa uji reliabilitas ialah kemampuan alat ukur untuk meghasilkan hasil pengukuran yang dapat dipercaya. Hasil pengukuran dapat dipercaya apabila dalam beberapa kali pengukuran pada kelompok objek yang sama diperoleh hasil yang relatif sama meskipun tetap ada toleransi bila terjadi perbedaan. Jika perbedaan sangat besar dari waktu ke waktu, maka hasil pengukuran tidak dapat dipercaya. Uji reliabilitas dalam penelitian ini menggunakan pendekatan cronbach alpha, apabila nilai koefisien cronbach alpha $>$ 0,60 maka construct dinyatakan reliabel. Dimana pada variabel Penerapan E- 
SPT (X1) memperoleh nilai cronbach alpha sebesar (0,949), variabel Kesadaran Wajib Pajak (X2) memperoleh nilai cronbach alpha sebesar $(0,941)$, Sanksi Perpajakan (X3) memperoleh nilai cronbach alpha sebesar $(0,917)$, dan Kepatuhan Wajib Pajak memperoleh nilai cronbach alpha sebesar $(0,964)$ sehingga dapat dikatakan bahwa seluruh variabel dalam penelitian ini dapat dinyatakan reliabel.

Tabel 3.

Uji Normalitas

One-Sample Kolmogorov-Smirnov Test

\begin{tabular}{llr} 
& & Unstandardized Residual \\
\hline $\mathrm{N}$ & & 100 \\
\hline Normal Parameters & Mean & .0000000 \\
\cline { 2 - 3 } & Std. Deviation & 572.96252053 \\
\hline Most Extreme Differences & Absolute & .080 \\
\cline { 2 - 3 } & Positive & .063 \\
\cline { 2 - 3 } & Negative & -.080 \\
\hline Test Statistic & & .080 \\
\hline Asymp. Sig. (2-tailed) & & $.118^{c}$ \\
\hline
\end{tabular}

a. Test distribution is Normal.

b. Calculated from data.

c. Lilliefors Significance Correction.

Sumber: Hasil Olah Data SPSS 26, 2020

Uji normalitas yang digunakan dalam penelitian ini dilakukan dengan menggunakan one - sample kolmogrov smirnov. Hasil uji normalitas dalam penelitian ini memperoleh nilai signifikan sebesar $0,118>0,05$ maka dapat disimpulkan bahwa data yang digunakan dalam penelitian ini berdistribusi normal sehingga model regresi pada penelitian ini layak untuk digunakan.

Uji Multikolinearitas dalam penelitian ini diukur dengan melihat nilai tolerance dan VIF (Variance Inflation Factor). Hasil uji multikolinearitas dalam penelitian ini memperoleh nilai tolerance dan vif pada masing-masing variable independent adalah sebagai berikut: (1) Penerapan E-SPT diperoleh nilai tolerance sebesar $0,462>0,10$ dan nilai vif sebesar 2,164<10, (2) Kesadaran 
wajib pajak diperoleh nilai tolerance sebesar $0,447>0,10$ dan nilai vif sebesar 2,236 < 10, (3) Sanksi Perpajakan diperoleh nilai tolerance sebesar 0,563>0,10 dan nilai vif sebesar $1,776<10$. Sehingga dapat disimpulkan bahwa data yang digunakan pada penelitian ini menunjukkan tidak terjadi multikolinearitas antar variable independen.

Tabel 4.

Uji Multikolinearitas

\begin{tabular}{|c|c|c|c|c|c|c|c|}
\hline \multicolumn{8}{|c|}{ Coefficients $^{a}$} \\
\hline \multirow[b]{2}{*}{ Model } & \multicolumn{2}{|c|}{$\begin{array}{l}\text { Unstandardized } \\
\text { Coefficients }\end{array}$} & \multirow{2}{*}{$\begin{array}{c}\text { Standardize } \\
\text { d } \\
\text { Coefficients } \\
\text { Beta }\end{array}$} & \multirow[b]{2}{*}{$t$} & \multirow[b]{2}{*}{ Sig. } & \multicolumn{2}{|c|}{$\begin{array}{l}\text { Collinearity } \\
\text { Statistics }\end{array}$} \\
\hline & B & Std. Error & & & & $\begin{array}{l}\text { loleran } \\
\text { ce }\end{array}$ & VIF \\
\hline 1 (Constant) & $\begin{array}{r}8130.40 \\
2\end{array}$ & 1364.262 & & 5.960 & $\begin{array}{r}.00 \\
0\end{array}$ & & \\
\hline $\begin{array}{l}\text { TOTAL_X } \\
1\end{array}$ & .190 & .090 & .188 & 2.107 & $\begin{array}{r}.03 \\
8 \\
\end{array}$ & .462 & 2.164 \\
\hline $\begin{array}{l}\text { TOTAL_X } \\
2\end{array}$ & .475 & .091 & .472 & 5.195 & $\begin{array}{r}.00 \\
0\end{array}$ & .447 & 2.236 \\
\hline $\begin{array}{l}\text { TOTAL_X } \\
3\end{array}$ & .241 & .078 & .248 & 3.066 & $\begin{array}{r}.00 \\
3\end{array}$ & .563 & 1.776 \\
\hline
\end{tabular}

a. Dependent Variable: TOTAL_Y

Sumber : Data diolah,2020

Tabel 5.

Uji Heteroskedastisitas

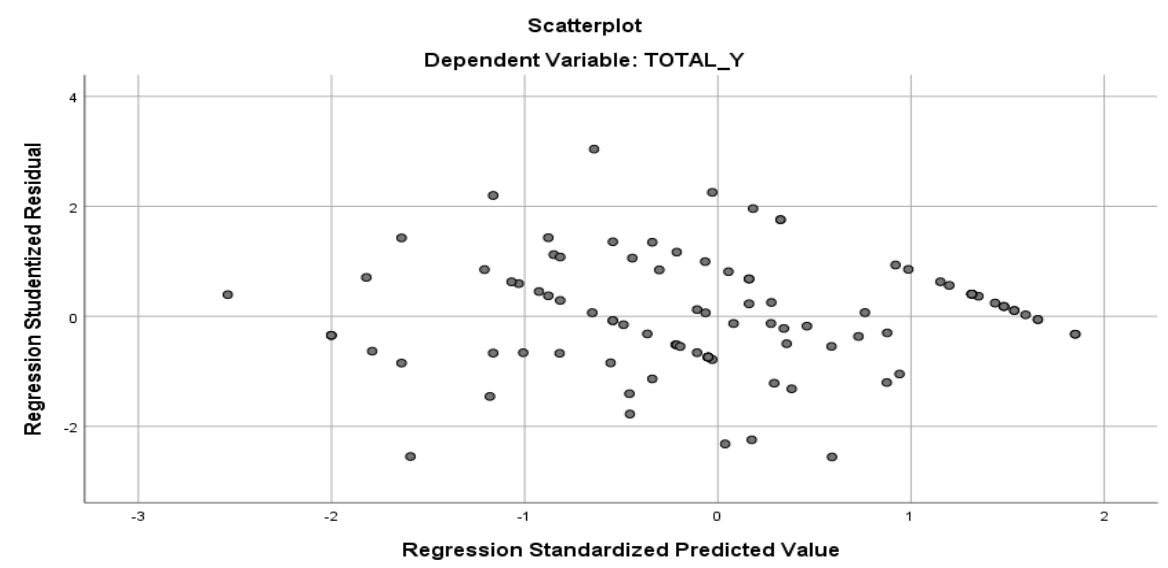

Sumber: Hasil Olah Data SPSS 26, 2020 
Uji heteroskedastisitas dalam penelitian ini dapat dilihat pada grafik scatter plot. Hasil uji heteroskedastisitas dalam penelitian ini menunjukkan bahwa titik-titik data menyebar diatas dan dibawah atau disekitar angka 0 , titik-titik data tidak mengumpul hanya diatas atau dibawah saja, penyebaran titik-titik data tidak boleh membentuk pola bergelombang melebar kemudian menyempit dan melebar kembali, dan penyebaran titik-titik data tidak berpola. Sehingga dapat disimpulkan bahwa pada data tersebut tidak menunjukkan gejala heteroskedastisitas.

Analisis deskriptif pada penelitian ini menggunakan skala ordinal dan rentang skala untuk menganalisis data yang diperoleh dengan cara menggambarkan Pengaruh Penerapan E-SPT, Kesadaran Wajib Pajak dan Sanksi Perpajakan Terhadap Kepatuhan Wajib Pajak. Asil analisis deskripti dalam penelitian ini dapat diliat pada asil rekapitulasi indikator masing-masing variabel.

Hasil analisis deskriptif pada variabel Penerapan E-SPT menunjukan bahwa total skor pada variabel bebas yaitu Penerapan E-SPT sebesar 2142 dengan nilai rata-rata sebesar 428,4 yang berada pada rentang skala 420,1 - 500 dengan kriteria sangat setuju, hal ini menggambarkan bahwa Penerapan E-SPT di KPP Pratama Karawang Utara telah memenuhi dimensi dalam tata cara penyampaian E-SPT. Terdapat 2 indikator dengan 5 pernyataan, dimana skor tertinggi dan terendah berada pada indikator ke -1 yaitu mengenai mengisi data-data perpajakan dengan menggunakan E-SPT dimana skor tertinggi diperoleh sebesar 443 pada peryataan ke -1 dan skor terendah sebesar 407 pada pernyataa ke - 2 . Hal ini disebabkan karena adanya persepsi dari sebagian responden yang merasa 
bahwa sistem E-SPT masih sulit untuk dipelajari terutama bagi WPOP yang belum pernah menggunakan sistem E-SPT tersebut (pemula). Sehingga hal tersebut dapat berakibat pada rendahnya tingkat kepatuhan wajib pajak di KPP Pratama Karawang Utara. Rahayu (2017) mengatakan bahwa apabila sistem administrasi perpajakan suatu Negara akan efektif apabila didukung oleh instansi pajak yang efektif, sehingga hal tersebut dapat memudahkan petugas pajak dan wajib pajak untuk memeriksa, membayarkan dan melaporkan kewajiban perpajakannya.

Selanjutnya hasil analisis deskriptif pada variabel Kesadaran Wajib Pajak menunjukkan bahwa total skor pada variabel bebas yaitu Kesadaran Wajib Pajak sebesar 1666 dengan nilai rata-rata sebesar 416,5 yang berada pada rentang skala 340,1 - 420 dengan kriteria setuju, hal ini menggambarkan bahwa WP OP di KPP Pratama Karawang Utara telah memenuhi dimensi dalam memahami peraturan perpajakan dan fungsi perpajakan. Terdapat 4 indikator dengan 4 pernyataan, dimana skor tertinggi berada pada indikator ke -2 yaitu mengenai memahami bahwa kewajiban perpajakan harus dilaksanakan sesuai dengan ketentuan yang berlaku dan skor terendah berada pada indikator ke -1 yaitu mengenai mengetahui adanya undang-undang dan ketentuan perpajakan, hal ini disebabkan karena sebagian reponden masih belum mengetahui dan memahami adanya undang-undang dan ketentuan perpajakan. Sehingga hal tersebut dapat berakibat pada rendahnya tingkat kepatuhan wajib Pajak di KPP Pratama Karawang Utara. 
Rahayu (2017) mengatakan bahwa apabila kemauan dan kesadaran wajib pajak tinggi maka akan memberikan dampak kepada kepatuhan perpajakan yang lebih baik lagi, sehingga penerimaan pajak diharapkan dapat mencapai target yang telah ditetapkan. Karena kesadaran wajib pajak salah satunya adalah wajib pajak mengetahui dan memahami peraturan undang-undang dan ketentuan perpajakan, sehingga hal tersebut dapat mendorong wajib pajak untuk patuh akan kewajiban perpajakannya.

Selanjutnya hasil analisis deskriptif pada variable Sanksi Perpajakan menunjukan bahwa total skor pada variable bebas yaitu Sanksi Perpajakan sebesar 2641 yang berada pada rentang skala 340,1 - 420 dengan kriteria setuju, hal ini menggambarkan bahwa WP OP di KPP Pratama Karawang Utara telah mematuhi peraturan mengenai Sanksi yang tela ditetapkan. Terdapat 7 indikator dengan 7 pernyataan, dimana skor tertinggi berada pada indikator ke -6 yaitu mengenai mengisi SPT sesuai Peraturan dan skor terendah berada pada indikator ke -3 yaitu mengenai sanksi administrasi pajak, hal ini disebabkan karena adanya persepsi dari sebagian responden yang merasa keberatan terhadap sanksi perpajakan yaitu berupa sanksi administrasi perpajakan dalam hal denda sebesar $50 \%$ dan pajak kurang bayar. Sehingga hal tersebut tentu saja dapat berpengaruh terhadap tingkat kepatuhan wajib pajak dalam melakukan kewajiban perpajakannya. Maka dalam hal ini, diperlukan adanya suatu ketegasan yang diberikan petugas pajak kepada wajib pajak agar patuh akan kewajiban perpajakannya. 
Rahayu (2017) mengatakan bahwa kepatuhan perpajakan dapat ditingkatkan melalui tekanan kepada wajib pajak untuk tidak melakukan pelanggaran atau tindakan illegal dalam usahanya untuk menyeludupkan pajak, tindakan yang diberikan tersebut berupa pemberian sanksi perpajakan kepada wajib pajak yang melanggar. Dalam hal ini pihak instansi pajak dapat memberikan suatu tindakan kepada wajib pajak yaitu dengan memberikan sanksi apabila diketahui wajib pajak tersebut telah melakukan pelanggaran perpajakan.

Selanjutnya hasil analisis deskriptif pada variable Kepatuhan Wajib Pajak menunjukan bahwa total skor pada variable bebas yaitu Kepatuhan Wajib Pajak sebesar 3395 dengan nilai rata-rata sebesar 424,4 yang berada pada rentang skala 420,1 - 500 dengan kriteria sangat setuju, hal ini menggambarkan bahwa WP OP di KPP Pratama Karawang Utara telah patuh akan kewajiban perpajakannya. Terdapat 7 indikator dengan 8 pernyataan, dimana skor tertinggi berada pada indikator ke -4 yaitu mengenai menyampaikan SPT tiap tahun dan skor terendah berada pada indikator ke -3 yaitu mengenai menghitung dan melaporkan tepat waktu, hal ini disebabkan karena adanya sebagian responden yang belum melaporkan SPT dan menyetorkan kewajiban perpajakannya secara tepat waktu setiap bulan. Sehingga diperlukan adanya suatu sistem administrasi perpajakan yang lebih efektif yang didukung oleh sumberdaya pegawai pajak yang mumpuni, adanya kemauan dan kesadaran wajib pajak untuk dapat memahami mengenai arti dan tujuan dari adanya pembayaran kewajiban perpajakan, dan kualitas penegakan hukum perpajakan berupa sanksi perpajakan di KPP Pratama Karawang Utara, sebab hal tersebut sangat penting agar dapat 
memotivasi wajib pajak untuk melakukan kewajiban perpajakannya.

Untuk mengetahui apakah terdapat pengaruh simultan varibel Pegaruh Penerapan E-SPT, Kesadaran Wajib Pajak dan Sanksi Perpajakan terhadap Kepatuhan Wajib Pajak di KPP Pratama Karawang Utara yang dilakukan dengan pengujian koefisien regresi dengan menggunakan uji F. Pengujian tersebut dilakukan dengan menggunakan alat bantu SPSS 26 dengan membandingkan F hitung dengan $\mathrm{F}$ tabel dan dapat dilihat dari nilai signifikasinya. Hasil Pengujian hipotesis secara simultan adalah sebagai berikut :

\section{Tabel 6.}

Uji Statistik f

\begin{tabular}{llr|r|r|r|r}
\multicolumn{7}{c}{ ANOVA } \\
Model & & Sum of Squares & \multicolumn{1}{c}{ Df } & Mean Square & \multicolumn{1}{c}{ F } & Sig. \\
\hline 1 & Regression & 59209905.217 & 3 & 19736635.072 & 58.298 & $.000^{\mathrm{b}}$ \\
\cline { 2 - 8 } & Residual & 32500318.943 & 96 & 338544.989 & & \\
\cline { 2 - 8 } & Total & 91710224.160 & 99 & & & \\
\hline
\end{tabular}

a. Dependent Variable: Kepatuhan WPOP

b. Predictors: (Constant), Sanksi Perpajakan, Penerapan E-SPT, Kesadaran Wajib Pajak Sumber: Hasil olah Data SPSS 26,2020

Hasil pengujian menunjukan bahwa Penerapan E-SPT, Kesadaran Wajib Pajak, dan Sanksi Perpaakan berpengaruh positi terhadap Kepatuhan Wajib Pajak, dengan nilai signifikan sebesar $0,000<0,05$ dan diperoleh nilai $\mathrm{F}$ hitung sebesar 58,298 > F tabel sebesar 3,09. Berdasarkan hasil pengujian tersebut menunjukkan bahwa Penerapan E-SPT, Kesadaran Wajib Pajak, dan Sanksi Perpajakan mempengaruhi Kepatuhan Wajib Pajak. Dimana semakin efektifnya sistem administrasi Negara yaitu sistem E-SPT, kemauan dan kesadaran wajib pajak semakin meningkat dan semakin berkualitasnya penegakan hukum perpajakan yaitu sanksi perpajakan bagi para pelanggarnya, maka akan mengakibatkan 
meningkatnya tingkat kepatuhan wajib pajak. Hasil penelitian ini sesuai teori yang dikemukakan oleh Rahayu (2017) mengatakan bahwa terdapat beberapa faktor yang mempengaruhi kepatuhan wajib pajak tiga diantaranya adalah kondisi sistem administrasi perpajakan disuatu Negara, kemauan dan kesadaran wajib pajak, dan kualitas penegakan hukum berupa sanksi perpajakan. Hasil penelitian ini sejalan dengan penelitian yang dilakukan oleh Halawa \& Saragih (2017), dimana hasil penelitian tersebut menyatakan bahwa kesadaran perpajakan dan sanksi perpajakan berpengaruh positif dan signifikan terhadap variabel kepatuhan wajib pajak.

\section{Tabel 7.}

\section{Analisis Regresi Linear Berganda}

\section{Coefficients $^{a}$}

\begin{tabular}{|c|c|c|c|c|c|c|}
\hline \multirow{2}{*}{\multicolumn{2}{|c|}{ Model }} & \multicolumn{2}{|c|}{ Unstandardized Coefficients } & \multirow{2}{*}{$\begin{array}{c}\text { Standardized } \\
\text { Coefficients } \\
\text { Beta }\end{array}$} & \multirow[b]{2}{*}{$\mathrm{t}$} & \multirow[b]{2}{*}{ Sig. } \\
\hline & & B & Std. Error & & & \\
\hline 1 & (Constant) & 8130.402 & 1364.262 & & 5.960 & .000 \\
\hline & Penerapan E-SPT & .190 & .090 & .188 & 2.107 & .038 \\
\hline & Kesadaran Wajib Pajak & .475 & .091 & .472 & 5.195 & .000 \\
\hline & Sanksi Perpajakan & .241 & .078 & .248 & 3.066 & .003 \\
\hline
\end{tabular}

a. Dependent Variable: Kepatuhan WPOP

Sumber: Hasil olah Data SPSS 26,2020

Berdasarkan hasil persamaan diatas, diketahui bahwa nilai konstanta sebesar 8130,402 yang berarti apabila variabel terikat yaitu Kepatuhan Wajib Pajak (Y) tidak dipengaruhi oleh variabel bebas yaitu Penerapan E-SPT (X1), Kesadaran Wajib Pajak (X2), dan Sanksi Perpajakan (X3) sama dengan 0 (nol) maka rata-rata kepatuhan wajib pajak akan bernilai sebesar 8130,402. Nilai koefisien regresi pada masing-masing variabel bebas menggambarkan apabila diperkirakan variabel bebas naik satu unit dan variabel bebas lainnya diperkirakan konstan atau setara dengan nol, maka variabel terikat diperkirakan bisa naik atau 
turun sesuai dengan tanda koefisien regresi linear berganda.

Koefisien regresi untuk variabel X1 yaitu Penerapan E-SPT bernilai positif, yang artinya terdapat suatu hubungan yang searah antara Penerapan ESPT (X1) dengan Kepatuhan Wajib Pajak (Y). Koefisien regresi X1 sebesar 0,190 berarti bahwa setiap kenaikan Penerapan E-SPT sebesar satu poin maka kepatuhan wajib pajak mengalami kenaikkan sebesar 0,190 . Koefisien regresi untuk variabel X2 yaitu Kesadaran Wajib Pajak bernilai positif, yang artinya terdapat suatu hubungan yang searah antara Kesadaran Wajib Pajak (X2) dengan Kepatuhan Wajib Pajak (Y). Koefisien regresi X2 sebesar 0,475 berarti bahwa setiap kenaikan Kesadaran Wajib Pajak sebesar satu poin maka kepatuhan wajib pajak mengalami kenaikkan sebesar 0,475 . Koefisien regresi untuk variabel X3 yaitu Sanksi Perpajakan bernilai positif, yang artinya terdapat suatu hubungan yang searah antara Sanksi Perpajakan (X3) dengan Kepatuhan Wajib Pajak (Y). Koefisien regresi X3 sebesar 0,241 berarti bahwa setiap kenaikan Sanksi Perpajakan sebesar satu poin maka kepatuhan wajib pajak mengalami kenaikkan sebesar 0,241 .

Hasil pengujian menunjukan bahwa Penerapan E-SPT berpengaruh positif dan signifikan terhadap Kepatuhan Wajib Pajak Orang Pribadi, dengan nilai signifikasi sebesar $0,038<0,05$ dan diperoleh nilai t hitung sebesar 2,107 $>\mathrm{t}$ tabel sebesar 1,98498. Dalam hal ini karena sistem administrasi perpajakan yaitu sistem E-SPT merupakan salah satu faktor yang dapat mempengaruhi kepatuhan wajib pajak maka sistem E-SPT tersebut harus berjalan sesuai dengan yang diharapkan dan wajib pajak dapat mengetahui dan memahami sistem E-SPT 
tersebut agar dapat melakukan kewajiban perpajakannya, sehingga hal tersebut akan mengakibatkan meningkatnya tingkat kepatuhan wajib paja di KPP Pratama Karawang Utara. Dengan demikian, dapat disimpulkan bahwa apabila penerapan E-SPT dapat berjalan secara efektif maka akan meningkatkan kepatuhan wajib pajak dalam melakukan kewajiban perpajakannya. Hasil penelitian ini sesuai teori yang dikemukakan oleh Rahayu (2017) mengatakan bahwa apabila sistem administrasi perpajakan suatu Negara akan efektif apabila didukung oleh instansi pajak yang efektif, sehingga hal tersebut dapat memudahkan petugas pajak dan wajib pajak untuk memeriksa, membayarkan dan melaporkan kewajiban perpajakannya. Hasil penelitian ini sejalan dengan penelitian yang dilakukan oleh Tabrani \& Raharjo (2019) dimana hasil penelitian tersebut menyatakan bahwa penerapan E-SPT berpengaruh signifikan terhadap kepatuhan wajib pajak.

Hasil pengujian menunjukan bahwa kesadaran wajib pajak berpengaruh positif dan signifikan terhadap Kepatuhan Wajib Pajak Orang Pribadi, dengan nilai signifikasi sebesar $0,000<0,05$ dan diperoleh nilai t hitung sebesar 5,195 $>\mathrm{t}$ tabel sebesar 1,98498. Dalam hal ini kesadaran wajib pajak masih perlu ditingkatkan kembali untuk melakukan kewajiban perpajakannya, sebab hal tersebut dapat mengakibatkan meningkatnya tingkat kepatuhan wajib pajak di KPP Pratama Karawang Utara. Dengan demikian, dapat disimpulkan bahwa apabila kesadaran waib pajak meningkat maka akan meningkatkan kepatuhan wajib pajak dalam melakukan kewajiban perpajakannya. Hasil penelitian ini sesuai dengan teori yang di kemukakan oleh Rahayu (2017) mengatakan bahwa apabila kemauan dan kesadaran wajib pajak tinggi maka akan memberikan 
dampak kepada kepatuhan perpajakan yang lebih baik lagi, sehingga penerimaan pajak diharapkan dapat mencapai target yang telah ditetapkan. Hasil penelitian ini sejalan dengan penelitian yang dilakukan oleh Halawa \& Saragih (2017), dimana hasil penelitian tersebut menyatakan bahwa kesadaran wajib pajak berpengaruh positif dan signifikan terhadap variabel kepatuhan wajib pajak.

Hasil pengujian menunjukan bahwa Sanksi Perpajakan berpengaruh positif dan signifikan terhadap Kepatuhan Wajib Pajak Orang Pribadi, dengan nilai signifikasi sebesar $0,003<0,05$ dan diperoleh nilai t hitung sebesar 3,066 > t tabel sebesar 1,98498. Dalam hal ini ketegasan dalam pemberian sanksi kepada para pelanggarnya tentu sangat diperlukan, dimana sanksi yang diberikan dapat berupa sanksi administrasi dan sanksi pidana. Tekanan yang diberikan petugas pajak kepada para pelnaggarnya tentu dapat mengakibatkan meningkatnya tingkat kepatuhan wajib pajak di KPP pratama Karawang Utara. Dengan demikian, dapat disimpulkan bahwa apabila dalam penerapan sanksi perpajakan semakin baik maka akan meningkatkan tingkat kepatuhan wajib pajak di KPP Pratama Karawang Utara untuk melakukan kewajiban perpajakannya.Hasil penelitian ini sesuai dengan teori yang di kemukakan oleh Rahayu (2017) mengatakan bahwa kepatuhan perpajakan dapat ditingkatkan melalui tekanan kepada wajib pajak untuk tidak melakukan pelanggaran atau tindakan illegal dalam usahanya untuk menyeludupkan pajak, tindakan yang diberikan tersebut berupa pemberian sanksi perpajakan kepada wajib pajak yang melanggar. Hasil penelitian ini sejalan dengan penelitian yang dilakukan oleh Halawa \& Saragih (2017), dimana hasil penelitian tersebut menyatakan bahwa sanksi perpajakan berpengaruh positif dan 
signifikan terhadap variabel kepatuhan wajib pajak.

Tabel 8.

Uji Koefisien Determinasi

\begin{tabular}{|c|c|c|c|c|}
\hline \multirow[b]{2}{*}{ Model } & \multicolumn{3}{|c|}{ Model Summary } & \multirow[b]{2}{*}{$\begin{array}{l}\text { Std. Error of the } \\
\text { Estimate }\end{array}$} \\
\hline & $\mathrm{R}$ & R Square & $\begin{array}{l}\text { Adjusted R } \\
\text { Square }\end{array}$ & \\
\hline 1 & $.804^{\mathrm{a}}$ & .646 & .635 & 581.846 \\
\hline
\end{tabular}

a. Predictors: (Constant), Sanksi Perpajakan, Penerapan E-SPT, Kesadaran Wajib Pajak

b. Dependent Variable: Kepatuhan WP OP

Sumber: Hasil olah Data SPSS 26,2020

Berdasarkan pengolahan data diatas, nilai koefesien determinasi (R2) yang ditunjukkan dalam kolom R Square yaitu sebesar 0,646 atau sebesar 64,6\%. Sehingga dapat disimpulkan bahwa variabel bebas yaitu Penerapan E-SPT, Kesadaran Wajib Pajak dan Sanksi Perpajakan berpengaruh sebesar 64,6\% terhadap Kepatuhan Wajib Pajak di KPP Pratama Karawang Utara, sedangkan sisanya sebesar $35,4 \%$ Kepatuhan Wajib Pajak dipengaruhi oleh variabel lain yang tidak diteliti dalam penelitian ini.

\section{SIMPULAN DAN SARAN}

Berdasarkan hasil uji t untuk H1 menunjukan bahwa Penerapan E-SPT secara parsial berpengaruh postitif dan signifikan terhadap Kepatuhan Wajib Pajak. Artinya, apabila semakin efektif penerapan sistem administrasi Negara yaitu sistem E-SPT, maka akan meningkatkan tingkat kepatuhan wajib pajak orang pribadi di KPP Pratama Karawang Utara. Berdasarkan hasil uji t untuk H2 menunjukan bahwa Kesadaran Wajib Pajak secara parsial berpengaruh positif dan signifikan terhadap Kepatuhan Wajib Pajak. Artinya, apabila semakin meningkatnya kemauan dan kesadaran wajib pajak dalam melakukan kewajiban perpajakannya, maka akan meningkatkan tingkat kepatuhan wajib pajak orang pribadi di KPP Pratama Karawang Utara. Berdasarkan hasil uji t untuk H3 
menunjukan bahwa Sanksi Perpajakan secara parsial berpengaruh positif dan signifikan terhadap Kepatuhan Wajib Pajak. Artinya, apabila semakin meningkatnya sanksi perpajakan yang diterapkan, maka akan meningkatkan tingkat kepatuhan wajib pajak di KPP Pratama Karawang Utara.

Bagi KPP Pratama Karawang Utara. Petugas pajak diharapkan dapat memberikan pengarahan berupa sosialisasi kepada wajib pajak orang pribadi agar dapat lebih memahami sistem E-SPT yang telah diterapkan untuk melakukan kewajiban perpajakan. Hal tersebut tentu saja dapat membuat wajib pajak semakin memahami penerapan sistem E-SPT tersbut dan dapat patuh akan kewajiban perpajakannya. Petugas pajak diharapkan dapat memberikan pengarahan berupa sosialisasi mengenai Undang-undang perpajakan dan ketentuannya agar wajib pajak orang pribadi sadar akan kewajiban perpajakannya, hal tersebut tentu dapat mengakibatkan wajib pajak patuh akan kewajiban perpajakannya. Dalam pemberian sanksi perpajakan kepada para wajib pajak diharapkan petugas pajak dapat melaksanakannya lebih tegas dan baik kepada para pelanggarnya, sehigga hal tersebut tentu dapat berakibat pada meningkatnya tingkat kepatuhan wajib pajak.

\section{REFERENSI}

Abdullah, A. (2019). Kamus Pajak. Yogyakarta: CV. ANDI OFFSET.

Agoes, S., \& Trisnawati, E. (2013). Akuntansi Perpajakan . Jakarta Selatan: Salemba Empat.

Alfisyahrin, M. (2018). Peningkatan Kualitas Pelayanan Publik di Indonesia. Jakarta: Yayasan Pustaka Obor Indonesia.

Ardiansyah, A., Kertahadi, \& Dewantara, R. Y. (2016). Pengaruh Pelayanan Fiskus Terhadap Kepatuhan Wajib Pajak Melalui Kepuasan Wajib Pajak 
(Studi pada Waib Pajak di Wilayah Kerja KPP Pratama Blitar). Jurnal Perpajakan (JEJAK), 11(1). 1-10.

Arifin, S. B., \& Nasution, A. A. (2017). Pengaruh Kualitas Pelayanan dan Sanksi Perpajakan Terhadap Kepatuhan Wajib Pajak Badan di KPP Pratama Medan Belawan. Jurnal Akuntansi dan Bisnis, 2(1). 1-177.

As'ari, N. G., \& Erawati, T. (2018). Pengaruh Pemahaman Peraturan Perpajakan, Kualitas Pelayanan, Kesadaran Wajib Pajak Dan Sanksi Pajak . Akuntansi Dewantara, 3(2). 2-52.

As'ari, N. G., \& Erawati, T. (2018). Pengaruh Pemahaman Peraturan Perpajakan, Kualitas Pelayanan, Kesadaran Wajib Pajak dan Sanksi Pajak Terhadap Kepatuhan Wajib Pajak Orang Pribadi. Akuntansi Dewantara, 3(2). 3-46.

Astana, I. S., \& Merkusiwati, N. L. (2017). Pengaruh Penerapan Sistem Administrasi Perpajakan Modern dan Kesadaran Wajib Pajak Pada Kepatuhan Wajib Pajak . E- Jurnal Akuntansi Universitas Udayana, 18(1). 818-846.

Ayza, B. (2017). Hukum Pajak Indonesia. Jakarta: Kencana.

Bahri, S. (2016). Pengantar Akuntansi berdasarkan SAK ETAP dan IFRS. Yogyakarta: CV. ANDI OFFSET.

Bahri, S., Diantimala, Y., \& Abd. Majid, M. S. (2018). Pengaruh Kualitas Pelayanan Pajak, Pemahaman Peraturan Perpajakan serta Sanksi Perpajakan Terhadap Kepatuahn Wajib Pajak (Pada Kantor Pajak KPP Pratama Kota Banda Aceh). Jurnal Perspektif Ekonomi Darussalam, 4(2). 1-318.

Dewi, C. S., \& Supadmi, N. L. (2014). Pengaruh Pemeriksaan Pajak, Kesadaran, Kualitas Pelayanan pada Tingkat Kepatuhan Wajib Pajak. E-Jurnal Akuntansi Universitas Udayana, 9(2) 505-514.

Dewi, L. P., \& Merkusiwati, N. K. (2018). Pengaruh Kesadaran Wajib Pajak, Sanksi Perpajakan, E- Felling, dan Tax Amnesty Terhadap Kepatuhan Pelaporan Wajib Pajak. E-Jurnal Akuntansi Universitas Udayana, 22(2).1626-1655.

Emanuel, A. W. (2017). Petunjuk Praktis Metode Penelitian Teknologi Informasi . Yogyakarta: CV. ANDI OFFSET.

Ermawati, W. D. (2018). Perpajakan Terapan Lanjutan. Malang: Polinema Press.

Ghozali, I. (2016). Aplikasi Analisis Multivariate Dengan Program IBM SPSS 23. Semarang: Universitas Dipenogoro. 
Halawa, J., \& Saragih, J. L. (2017). Pengaruh Kesadaran Perpajakan, Sanksi Pajak, Sikap Fiskus Terhadap Kepatuhan Wajib Pajak di KPP Pratama Lubuk Pakam. JRAK, 3(2).2443-1079.

Hantono, \& Rahmi, N. U. (2018). Pengantar Akuntansi. Yogyakarta: Deepublish.

Khulsum, U., \& Waluyo. (2019). The Effect Modernization Tax Administration System and Tax Service on Tax Compliance and Tax Knowledge as Moderation Variable. International Journal of Science and Research (IJSR), 8(9). 1097-1102.

Lingga, I. S. (2013). Pengaruh Penerapan E-SPT Terhadap Kepatuhan Pajak Studi Empiris Terhadap Pengusaha Kena Pajak Di Wilayah KPP Pratama. Jurnal Akuntansi, 5(1). 50-60.

Lubis, R. H. (2017). Pengaruh Kualitas Pelayanan Perpajakan, dan Sanksi Perpajakan Terhadap Kepatuhan Wajib Pajak di KPP Pratama Medan Belawan. Jurnal Konsep Bisns dan Manajemen, 4(1). 31-42.

Martani, D., Siregar, S. V., Wardhani, R., Farahmita, A., \& Tanujaya, E. (2016). Akuntansi Keuangan Menengah Berbasis PSAK. Jakarta: Salemba Empat.

Martini, Penawang, S. Y., \& Purnomo, T. B. (2019). Dampak Penerapan ESystem Perpajakan Terhadap Tingkat Kepatuhan Wajib Pajak Orang Pribadi Pada Kantor Pelayanan Pajak (KPP) Kantor Wilayah Jakarta Selatan. Jurnal Riset Manajemen dan Bisnis, 4(S1).764.

Mindarti, L. I. (2016). Manajemen Pelayanan Publik (Menuju Tata Kelola yang Baik). Malang: UB Press.

Muljono, D. (2010). Panduan Brevet Pajak (Akuntansi Pajak dan Ketentuan Umum Perpajakan). Yogyakarta: CV. ANDI OFFSET.

Mulyawan, R. (2016). Birokrasi dan Pelayanan Publik. Sumedang: UNPAD PRESS.

Narwanti, S. (2018). Perpajakan. Yogyakarta: Istana Media.

Nugroho, A., Andini, R., \& Raharjo, K. (2016). Pengaruh Kesadaran Wajib Pajak dan Pengetahuan Perpajakan Wajib Pajak Terhadap Kepatuhan Wajib Pajak Dalam Membayar Pajak Penghasilan (studi kasus pada KPP Semarang Candi). Journal Of Accounting, 2(2). 1-13.

Pandiangan , L. (2007). Modernisasi\& Reformasi Pelayanan Perpajakan Berdasarkan UU Terbaru. Jakarta: PT. Elex Media Komputindo.

Pebrina, R., \& Hidayatulloh, A. (2020). Pengaruh Penerapan E-SPT, Pemahaman Peraturan Peraturan Perpajakan, Sanksi Perpajakan, Dan Kualitas 
Pelayanan Terhadap Kepatuhan Wajib Pajak. Jurnal Ilmiah Ekonomi dan Bisnis, 17(1).1-8.

Pohan, C. A. (2016). Manajemen Perpajakan. Jakarta: Gramedia Pustaka Utama.

Prena, G. D., Kustina, K. T., Dewi, I. G., Putra, I. G., \& Krisnanda, R. A. (2019). Tax Sancsion, Tax Amnesty Program and Tax Obligation Placement towards Compliance Report on Corporate . International Journal of Social Sciences and Humanities, 3(1). 26-35.

Purwono, H. (2010). Dasar - Dasar Perpajakan \& Akuntansi Perpajakan . Jakarta: Erlangga.

Putra, I. N., \& Setiawan, P. E. (2020). The Effect of Taxpayer Awareness, Service Quality, Taxation Understanding, and application of E-filling system on Corporate Taxpayer Compliance. Amerian ournal of Humanities and Social Sciences Research (AJHSSR), 6(5). 175-183.

Rahayu, S. K. (2010). Perpajakan Indonesia Konsep dan aspek formal. Yogyakarta: Graha ilmu.

Rahayu, S. K. (2017). Perpajakan (Konsep dan Aspek Formal). Bandung: Rekayasa Sains.

Rahayu, S. K. (2017). Perpajakan konsep dan aspek formal. Bandung: Rekayasa Sains.

Resmi, S. (2016). Perpajakan Teori dan Kasus. Jakarta: Salemba Empat.

Resmi, S. (2019). Perpajakan Teori\& Kasus. Jakarta Selatan: Salemba Empat.

Rochaety, E., Tresanati, R., \& Latief, A. (2019). Metodologi Penelitian Bisnis dengan Aplikasi SPSS. Jakarta: Mitra Wacana Media.

Rochaety, E., Tresnati, R., \& Latief, A. M. (2019). Metodologi Penelitian Bisnis. Jakarta: Mitra Wacana Media.

Rofika, M., \& Sihar, T. (2017). Pengaruh Kesadaran Wajib Pajak dan Sosialisasi Direktorat Jendral Pajak Terhadap Kepatuhan Wajib Pajak Dengan Pelaksanaan Law Enforcement Sebagai Variabel Moderating . Media Akuntansi Perpajakan, 2(1). 27-34.

Sabil, Pujiwidodo, D., \& Lestiningsih, A. S. (2018). Pengaruh E-SPT Pajak Penghasilan Dan Pemahaman Pajak Terhadap Kepatuhan. Sikap, 2(2).122135.

Sagoro, E. M. (2015). Akuntansi Tanpa Stres. Yogyakarta: AB Publisher. 
SBR, T. K. (2017). Sanksi-Sanksi Perpajakan. Jakarta: Russell Bedford.

Simanjuntak, T. H., \& Mukhlis, I. (2012). Dimensi Ekonomi Perpajakan Dalam Pembangunan Ekonomi. Jakarta: Raih Asa Sukses .

Soemarso. (2014). Akuntansi Suatu pengantar. Jakarta: Salemba Empat.

Solekhah, P., \& Supriono. (2018). Pengaruh Penerapan Sistem E-Filing, Pemahaman Perpajakan, Kesadaran Wajib Pajak dan Sanksi Perpajakan Terhadap Kepatuhan Wajib Pajak Orang Pribadi di KPP Pratama Purworejo. JEMATech, 1(1). 74-91.

Sugiyono. (2016). Metode Penelitian Pendidikan Pendekatan Kuantitatif, Kualitatif dan $R \& D$. Bandung: Alfabeta.

Sugiyono. (2018). Metode Penelitian Kauntitatif, Kualitatif, dan R\&D. Bandung: ALFABETA.

Sugiyono. (2018). Metode Penelitian Pendidikan Pendekatan Kuantitatif, Kualitatif dan $R \& D$. Bandung: Alfabeta.

Suharyadi, \& Purwanto. (2016). Statistika untuk ekonomi dan keuangan modern. Jakarta: Salemba Empat.

Sujarweni, V. W. (2014). Metodologi penelitian. Yogyakarta: Pustaka Baru Press.

Sujarweni, W. V. (2016). Kupas Tuntas Penelitian Akuntansi dengan SPSS. Yogyakarta: Pustaka Baru Press.

Suliyanto. (2018). Metode Penelitian Bisnis. Yogyakarta: Andi Offset.

Suliyanto. (2018). Metode Penelitian Bisnis untuk Skripsi, Tesis, \& Disertasi. Yogyakarta: ANDI OFFSET.

Sumarsan, T. (2017). Perpajakan Indonesia : Pedoman Perpajakan yang Lengkap berdasarkan Undang-Undang Terbaru. Jakarta: Indeks.

Sumarsan, T. (2019). Perpajakan Indonesia Pedoman Perpajakan Yang Lengkap Berdasarkan Undang-Undang Terbaru. Jakarta: Indeks.

Susmita, P. R., \& Supadmi, N. L. (2016). Pengaruh Kualitas Pelayanan, Sanksi Perpajakan, Biaya Kepatuhan Pajak dan Penerapan E-Felling pada Kepatuhan Wajib Pajak. E-Jurnal Akuntansi Universitas Udayana, 14(2). 1239-1269.

Tabrani, \& Raharjo, T. B. (2019). Penerapan E-SPT, Tingkat Pemahaman Perpajakan, Kualitas Pelayanan, Dan Kesadaran Wajib Pajak Badan 
Dalam Melaporkan SPT Di KPP Pratama TEGAL. Jurnal Ilmu Manajemen dan Akuntansi Terapan (JIMAT), 10(2). 189-202.

Tarjo. (2019). Metode Penelitian Sistem 3 Kali Baca. Yogyakarta: DEEPUBLISH.

Wardani, D. K., \& Asis, M. R. (2017). Pengaruh Pengetahuan Wajib Pajak Kesadaran Wajib Pajak dan Program Samsat Corner Terhadap Kepatuhan Wajib Pajak Kendaraan Bermotor. Akuntansi Dewantara, 1(2). 106-116.

Widyaningsih, A. (2013). Hukum Pajak dan Perpajakan. Bandung: Salemba empat.

Wulandari, P. A., \& Iryanie, E. (2018). Pajak Daerah dalam Pendapatan Asli Daerah. Banjarmasin: Cv Budi Utama.

Zamzami, f., \& Nusa, N. D. (2017). Akuntansi Pengantar I. Yogyakarta: UGM Press.

Zulaikha, S. M. (2013). Pengaruh Kemanfaatan NPWP, Pemahaman Wajib Pajak, Kualitas Pelayan, Sanksi Perpajakan, Terhadap Kepatuhan Wajib Pajak. Dipenogoro Journal Of Accounting, 2(4). 1-15. 